\title{
'n Verstaan van God vir opbouende vernuwers - aldus Adrio König se teologie
}

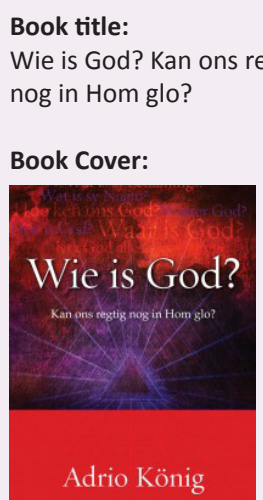

Author:

A. König

ISBN:

978-1-77000-959-2

\section{Publisher:}

Christelike

Uitgewersmaatskappy, 2012,

R139.95

*Book price at time of review

(1)

Review title:

'n Verstaan van God vir opbouende vernuwers -

aldus Adrio König se teologie

Reviewer:

Adriaan L. Rheeder

\section{Affiliation:}

School of Ecclesiastical

Sciences, North-West

University, Potchefstroom

Campus, South Africa

Email:

riaan.rheeder@nwu.ac.za

Postal address:

PO Box 62, Potchefstroom

2520, South Africa

How to cite this book review:

Rheeder, A.L., 2013, "n

Verstaan van God vir

opbouende vernuwers -

aldus Adrio König se teologie',

In die Skriflig/In Luce Verbi

47(1), Art. \#666, 2 pages.

http://dx.doi.org/10.4102/ids.

v47i1.666

\section{Read online:}

Scan this QR
code with your
smart phone or
mobile device
to read online.

Dit is interessant hoe tye kan verander. In die tagtigerjare, tydens my studentejare, was prof. König as 'n liberale en gevaarlike teoloog beskou. Vandag verteenwoordig hy die middelgrond tussen die fundamentalisme en die Nuwe Hervorming. Hierdie boek van König kan as 'n apologetiese werk teen sekere rigtings in die moderne teologie beskou word. Myns insiens is König meer verdraagsaam teenoor die fundamentalisme as teenoor die Nuwe Hervorming. Alhoewel König indirek kommentaar op die fundamentalisme lewer (bl. 31-32), doen hy dit nie op dieselfde besliste manier as teenoor ander wetenskaplikes nie (bv. Richard Dawkins, Abel Pienaar, Julian Müller, Anton van Niekerk en Willie Esterhuyse). Die terloopse verwysings na Izak Spangenberg laat nie reg geskied aan sy nuutste werk, Jesus van Nasaret, nie (bl. 81, 106, 120).

Die doel van hierdie boek is om die leser se geloof in God radikaal te vernuwe sodat hulle God op 'n ryker en opwindender manier kan beleef (bl. 20). Om aan hierdie doel uitvoering te gee, word 13 vrae in die boek gevra (sien die verkorte inhoudsopgawe) en beantwoord. In hierdie resensie sal verskeie vrae gevra word en König se (soms kontroversiële) antwoord sal telkens kortliks weergegee word. Hier en daar sal 'n kritiese vraag gevra word, met 'n samevattende beoordeling daarvan aan die einde.

Met betrekking tot die evolusie (Richard Dawkins), word die vraag in hoofstuk 1 gevra of God werklik bestaan. König antwoord dat '[d]it ... eenvoudig te veel gevra [is] om te aanvaar dat soveel wonderlike en self onbegryplike en asemrowende dinge vanself voortgekom het', maar hy erken ook dat die huidige werklikheid evolusionêr ontwikkel het (bl. 57). In hoofstuk 2 vra König of God tot dieselfde werklikheid as die mens behoort. Teenoor die beskouing van 'God in jou' (Abel Pienaar) of 'jy in God' (Julian Müller), antwoord König dat God en die werklikheid nie 'n ontologiese eenheid vorm nie, maar as 'twee' in 'n liefdesverbond leef (bl. 70). Dit is ook belangrik dat kennis geneem word van König se bespreking van 'n bybelse wêreldbeeld (bl. 75). In hierdie hoofstuk word die opmerking gemaak dat 'n ontwikkeling in die bonatuurlike wêreldbeeld wel in die Bybel gevind word (bl. 83, 116, 240-241), byvoorbeeld van die onskuldige Satan as aanklaer (Ou Testament) tot 'n dodelike vyand van God (Nuwe Testament). Die gedagte van ontwikkeling binne die Bybel kan 'n positiewe antwoord bied op byvoorbeeld God se handeling in Josua 10:11.

'Hoeveel weet ons van God?', vra König in hoofstuk 3. Hierdie vraag word gevra na aanleiding van Van Niekerk se bewering dat God die groot (byna onkenbare) Misterie is. Ons weet geweldig baie van God, skryf König (bl. 94), en dit wat ons van God weet, hoor ons uit getuienisse, belewenisse en die ervarings van mense oor God soos dit in die Bybel gevind word (bl. 95, 98 en 100). In hoofstuk 4 beantwoord König die vraag of almal dieselfde God dien. Willie Esterhuyse het die gedagte van 'n eksklusiewe godsdiens laat vaar en meen dat God in alle godsdienste gevind word (bl. 102). Hy lei hierdie gedagte af uit ooreenkomste tussen die godsdienste in die Bybel, Egipte en Kanaän, byvoorbeeld die oorwinning van die goed teenoor die kwaad (Osirisstorie), die heiligheid van God, God as Vader, die stem van God, 'n Drie-eenheid (Pta, Ra-Harakte en Amoen), asook die gebruik van die naam El vir God én die Kanaänitiese gode. König ontken nie die ooreenkomste tussen die godsdienste nie asook die feit dat die Bybel sekere buite-bybelse gedagtes oorgeneem het nie (bl. 103-104). Hy meen egter dat daar ook radikale verskille tussen die Egiptiese en die bybelse godsdienste is. König noem byvoorbeeld dat daar by die God van die Bybel geen sprake is van familie, seks en voortplanting nie (bl. 105 en 118). Daar kan met König saamgestem word dat daar selfs ingrypende verskille tussen die godsdienste in die Bybel, Egipte en Kanaän is en dat die Bybel in hierdie opsig uniek is. Ek betwyfel dit egter dat 'n mens uit die uniekheid die absolute waarheid van slegs een godsdiens kan aflei.

In hoofstuk 5 behandel König die wese van God en kies om oor God en Jesus te dink as die Een wat in vryheid lief het (bl. 140). Jesus se vryheid beteken dat Hy nie deur sy eie grootheid, belangrikheid en ambisie gebind was nie en daarom het Hy met liefde onder die randfigure in die samelewing gewerk (bl. 141-142). God se vryheid word verstaan as sy keuse om die mens lief

Copyright: ( 2013. The Authors. Licensee: AOSIS OpenJournals. This work is licensed under the Creative Commons Attribution License. 
te hê (bl. 215), selfs al verdien hulle nie sy liefde nie. As God nie vry was nie, sou Hy 'paslik' gereageer het op ontrou en die mens vir ewig verwerp het (bl. 143). God se dúúr liefde in Christus beteken die totale redding van die mens (bl. 147) asook die goed-wees vir sy vyande (bl. 155).

In hoofstukke 6 en 7 word God se Naam en benamings van naderby beskou. God het net een Naam, naamlik die eienaam Here (Jahwe). König pleit dat hierdie naam vir God in die Afrikaanse vertaling gebruik moet word (bl. 161). Die naam Jahwe dui God aan as die God wat nie net praat nie, maar wat dinge laat gebeur (bl. 164-165). 'Hoe is God?', vra König in hoofstuk 8 en beantwoord die vraag deur die eienskappe van God te bespreek. God is genadig, heilig, barmhartig, geregtig, getrou, geduldig en toornig. Volgens König is een van die eienskappe van God dat Hy soms gefrustreerd raak en daarom lyding ervaar. Frustrasie beteken dat God swaar kry (en dus ly) wanneer sy intense liefde openlik verwerp word (Jer 2:10-12; bl. 201, 209).

In die negende hoofstuk gee König aandag aan die vraag na God se almag. Teenoor Calvyn wat glo dat God die Vader die beskikker is van letterlik alles wat op die aarde gebeur (goed, kwaad en selfs misdaad; bl. 226-230), en Arminius wat oordeel dat God die sonde toelaat (bl. 230-232), meen König dat die Bybel God nie as 'n almagtige God beskryf wat enigiets enige tyd kan regkry nie. God kry dit byvoorbeeld nie reg om sy volk aan Hom gehoorsaam te hou nie (Jer 32:33; bl. 249). Hy sukkel om hulle te oorreed (bl. 269). Op die meeste kan die mens maar net bely dat God in 'n ruimer sin in beheer is - dit veronderstel 'n oop geskiedenis. Ruimer beheer impliseer dat dinge nie totaal handuit sal ruk nie en dat God sy doel met alles uiteindelik sal bereik (bl. 254-255). Voorsienigheid beteken dat God gelowiges innerlik sterk maak tydens hulle swaarkry (bl. 236-239). In die besigwees met hierdie hoofstuk ontwikkel 'n spanning in die verstaan daarvan dat God sukkel om sekere dinge op aarde reg te kry, maar tog gereeld daarin kon slaag om Israel te straf. Straf deur middel van die Babiloniërs as God se doelbewuste besluit (bl. 244, 249-250, 258) veronderstel tog 'n bepaalde invloed in die geskiedenis, politiek en die harte van baie mense!

In hoofstuk 10 bespreek König die vraag na God se betrokkenheid by die geskiedenis. Nie net God is by die geskiedenis betrokke nie, maar ook die mens, die bose magte en natuurwette (bl. 256-262). God en Jesus se voorsienigheid of betrokkenheid in die geskiedenis beteken die bewerking van enkele groot wendings (bv. die skepping en die koms van Jesus; bl. 259); die stryd teen en die oorwinning oor die bose magte (bl. 263); die stryd om die harte van mense (bl. 265-269); die ondersteuning in nood (bl. 263); en mense as God se helper in die stryd en oorwinning oor die bose (bl. 264). God ly nie nederlae teen die bose nie, maar wel in die harte van sy kinders (bl. 275-276).

König gee in hoofstuk 11 aandag aan die vraag hoe mensvormige verwysings na God verstaan moet word. König se antwoord kom daarop neer dat die klem van die Skrif nie op 'n mensvormige God val nie, maar wel daarop dat mense Godvormig moet wees (bl. 282). Tog onstaan die vraag of die mens op enige ander wyse oor God kan dink as mensvormig. God kan ook verander, meen König in hoofstuk 12. Die Skrif toon aan dat God soms jammer was dat Hy sekere mense gemaak het (Gen 6) en dat Hy eenvoudig van besluit verander het (Jona; bl. 294). Anders as suurstof, is God nie altyd oral op dieselfde wyse teenwoordig nie. Hy kies waar, wanneer en hoe Hy teenwoordig wil wees (bl. 302). God is Drie-enig en staan in verhouding met Homself (bl. 316) en ook in verhouding met die mens (bl. 320), skryf König in hoofstuk 13.

Die besondere waarde van hierdie boek word myns insiens gevind in die Skrifbeskouing, epistemologie en hermeneutiek wat in die teks vervleg is.

Die Bybel is God se openbaring (bl. 133) in die vorm van mense se getuienisse (bl. 95), belewenisse (bl. 98, 208) en eeue se ontmoetings en ervarings met God (bl. 110, 112, 128, 133 en 208). Die boodskap van die Bybel is nie altyd onmiddellik duidelik nie en daar is baie maniere om die Skrif te verstaan (bl. 29); daarom moet die insig van medegelowiges 'n mens help om nader aan die boodskap van die Bybel te beweeg (bl. 136). Die inhoud van die Bybel is ryk en die gelowiges moet soms betekenisse kies waarby hulle die meeste aanklank vind (bl. 137). In sommige sake is die Bybel egter nie so duidelik nie (bl. 214). Die interpretasie van die Skrif moet as voorlopig beskou word, terwyl sekere verklarings beter as andere is. Interpretasies van die Skrif bring altyd kritiese vrae na vore (bl. 270). Wanneer ' $n$ teoloog iets wat sinloos is, sinvol laat inpas, het die teoloog waarskynlik die pad byster geraak: die oorsprong en die voortgaan van die sonde kan dus nie verklaar word nie, maar moet bloot bely word (bl. 271). Onsekerheid is deel van die lewe (bl. 273-274) en soms is die Bybel onstellend in die sin dat dit nie verduidelik waarom God nie lyding keer nie (bl. 276). König is oortuig daarvan dat God nie uitgeredeneer kan word nie (bl. 95), maar dat die duidelikste kennis oor God in Jesus gevind kan word (bl. 141 en 145).

Die Bybel is 'n baie ou boek met somtyds vreemde mededelings daarin (bl. 136). Dit kan dus nie in alle opsigte letterlik vertolk word nie (bl. 31). In die verklaring van die Bybel moet gelowiges altyd bereid wees om hulle interpretasie van die Bybel te heroorweeg. Die Bybel self verander nie, maar wel die gelowige se interpretasie daarvan (bl. 31). Met dieselfde eerbied vir die Bybel kan gelowiges tot verskillende oortuigings oor die inhoud van die Bybel kom (bl. 33). Sekere sake in die Bybel het nie meer vir vandag betekenis nie, omdat daar duidelike ontwikkelings in die boodskap van die Skrif gevind word (bl. 240). Die Bybel kan op 'n 'plat' manier gebruik word: dus enige teks te eniger tyd en in enige verband, ongeag wanneer die gebeurtenis plaasgevind het en wat daarna gebeur het (bl. 241). Die interpreteerder se eie agtergrond en belangstelling bepaal ook die verstaan van die Bybel (bl. 137).

Alhoewel hierdie boek in populêre taal geskryf is, is die slotopmerking dat dit ' $n$ boek is waarvan teologiese studente ernstig moet kennis neem. Hierdie boek kan van groot waarde wees vir die (gereformeerde) lidmaat wat nie meer op 'n simplistiese en fundamentalistiese manier oor God wil dink nie. 